\title{
Evaluating the impacts of Income Transfer Programs in Latin America ${ }^{1}$
}

\author{
Maria Ozanira da Silva e Silva ${ }^{1}$ \\ http://orcid.org/0000-0003-0421-9934
}

\author{
Valéria Ferreira Santos de Almada Lima ${ }^{1,2}$ \\ http://orcid.org/0000-0002-3686-1895
}

${ }^{1}$ Universidade Federal do Maranhão, Programa de Pós-Graduação em Políticas Públicas, São Luís, MA, Brazil (UFMA)

${ }^{2}$ Universidade Federal do Maranhão, Departamento de Economia, São Luís, MA, Brazil (UFMA)

\section{Evaluating the impacts of Income Transfer Programs in Latin America}

Abstract: The methodological procedures used for conducting this study were bibliographic and document review, specifically of analyses of studies about conditional income transfer programs in Latin America. It focuses on three countries in a comparative study: Brazil, Argentina and Uruguay. The article presents the theoretical and empiric basis of the references about the evaluation of social policies and programs and conducts an analysis that considers the attainment of the immediate objectives of the programs analyzed in relation to their strategic objectives. It presents and problematizes possible impacts of the programs considered, highlighting the results identified in relation to indicators of poverty and social inequality, education, healthcare, nutrition and labor.

Keywords: Income transfer programs. Poverty. Impact. Latin America.

Received on 10.10.2017. Approved on 08.02.2018. Reviewed on 14.03.2018.

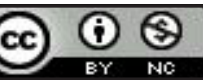

(C) The Author(s). 2018 Open Access This article is distributed under the terms of the Creative Commons Attribution-NonCommercial 4.0 International License (http://creativecommons.org/licenses/by-nc/4.0/), which permits use, distribution, and reproduction in any medium, since it's for non-commercial purposes, and provided you give appropriate credit to the original author(s) and the source, provide a link to the Creative Commons license, and indicate if changes were made. 


\section{Introduction}

This article is the product of studies conducted in the realm of the project Conditional Income Transfer Programs in Latin America: a comparative study - Family Grant (Brazil), New Regime for Family Allowances (AFAM-PE (Uruguay) and Universal Allowance per Child for Social Protection (Argenti$n a)$, initiated in July 2012 and concluded in July 2016. The comparative study was preceded by an exploratory study to develop a socio-economic and political contextualization of the rise and development of Conditional Income Transfer Programs in Latin America and the Caribbean ${ }^{2}$ and had participation from the Graduate Program in Public Policies of the Federal University of Maranhão (the general coordinator of the Project); the Graduate Program in Social Work of the Pontifical Catholic University of São Paulo (PUC-SP); the Graduate Program in Social Work of the Pontifical Catholic University of Rio Grande do Sul; the Doctoral Program in the Social Sciences of the College of Social Sciences of the University of the Republic, Uruguay, and the Master's Program in Social Sciences of the College of the Human Sciences of the National University of the Center of the Province of Buenos Aires, Argentina.

In general terms, the comparative study between the three conditional income transfer programs mentioned sought to establish convergences, divergences and specificities among ten dimensions that shape the contents of income transfer programs in Latin America, such as: contextualization and antecedents of the three programs; the concept of poverty that guides these programs; their conditionalities, focus, administration, work, budget, possible impacts, the role of families as beneficiaries of the programs and the monetary and non-monetary benefits provided by the programs. Nevertheless, this article focuses on the evaluation of possible impacts of these Latin American income transfer programs, which is one of the dimensions considered in the comparative study and which is important for understanding any changes in the immediate living conditions and in the scope of the strategic objects of these programs. We begin with the understanding that the conditional income transfer programs implemented in Latin America propose to combine immediate objectives, represented by improvements in the living conditions of their beneficiaries, with strategic objectives aimed at changes in the lives and form of social insertion of their beneficiaries, which means "removing the recipients from the situation of poverty and improving their well-being in basic issues, and to contribute to the formation of human capital so that they can have an effective insertion in the society from which they are excluded". (SILVA et al., 2016, p. 247). The immediate objectives are expressed by indicators such as income, registration rates and attendance in formal schooling, the number of visits for pediatric and or gynecological care, etc. (SILVA et al., 216), whose scope has been identified by studies conducted almost always during the period that the families were inserted in the programs.

The paper first presents the theoretical-empiric reference base for the analysis and a problematization of the possible impacts of these Latin American income transfer programs, to then indicate the more relevant impacts identified in the study, considering indicators of poverty and social inequality, as well as indicators of education, health, nutrition and food and nutritional safety; and indicators about labor of adults and children. The paper is completed with some concluding reflections.

\section{Theoretical-empiric base for the analysis of possible impacts of income transfer programs in Latin America}

The theoretical empirical foundation that supports the reflections constructed in this article, and that guide the construction of the meaning and reality of possible impacts of the conditional income transfer programs, considers immediate changes in the living conditions of the beneficiary families. But it also seeks to articulate these changes with the possibility of attaining the strategic objectives of the programs under focus, which as a rule are related with what they denominate as overcoming intergenerational poverty. This is because the majority of the studies conducted of these programs have simply revealed what is mainly in the strategic objectives, although these evaluative studies have given little attention to this fact. The findings have mainly focused on the and isolated improvements in living conditions of the beneficiaries, without analyzing if there have been significant and long-lasting changes (SILVA; LIMA, 2014). Following this line, these evaluative studies have focused on indicators such as increased income, registration and attendance rates informal schooling, the number of visits for pediatric and or gynecological care, and the vaccination and weighing of children, which represent the immediate objectives directly related to compliance with the conditionalities. Moreover, these evaluations seek to identify these immediate impacts only during the time that the families are beneficiaries of the programs, so that those who leave are absent from the studies and research, as identified by Silva and others $(2017)^{3}$. To the degree to which the intervention in the income 
transfer programs is focused on healthcare and education, which are fields of conditionalities, the programs generate products that are necessarily expected, due to the monetary and non-monetary benefits provided in these specific fields. From this perspective, Bentura Alonso and Vecinday Garrido (2013) classify these evaluations of impacts as tautological:

For the purposes of the analysis proposed here we qualify an evaluation as tautological when the evaluative indicator is about that which is operated by the intervention that is evaluated. In the case that concerns us, the evaluation is tautological because it "transferred income and measured income" to determine the success of the conditional income transfer program in fighting poverty. (BENTURAALONSO; VECINDAY GARRIDO, 2013, p. 143).

Based of this understanding, we consider immediate objectives to be those limited to altering specific and immediate living conditions of the people and strategic objectives those formulated by the income transfer programs that "consist in removing the recipients from the situation of poverty and improving their well-being in basic questions, and are designed to contribute to the formation of human capital to allow them an effective insertion in the society from which they are excluded". (SILVA, 2016, p. 5-6). Understood in this way, an evaluation of

\section{[...] an evaluation of the impact}

that aims to reveal the scope of the possible strategic objectives of income transfer programs should go beyond the identification of improvement of poverty indicators as simply
additional income [...]

In summary, we work with the concept of evaluation of the impact according to the definition used by Roche (2000, p. 37), who affirms that "evaluation of impact is the systematic analysis of the long lasting or significant changes - positive or negative, planned or not, in the lives of the people and caused by a certain action or series of actions". To evaluate actions is to try to know the effects (positive and negative) of the policy, project or program on the target subjects and about the reality in which the intervention takes place. These effects can be technical, economic, political, sociocultural, institutional and environmental, given that the social policies and programs have impact on multiple dimensions on social reality, and at the same time, are impacted by the reality within which they are implemented. This means that all evaluation implies making a judgment about the merit of a policy or program according to criteria of efficiency and effectiveness (SILVA, 2013). Moreover, it is understood that: "A good and complete evaluation judges and explains" (NEMES, 2001, p. 10), and should reveal the reasons for the success or failure of a policy or program. We thus understand that the evaluation of social policies and programs have three essential functions: technical, political and academic:

Through the technical function, it will provide support to the correction of deviations during the implementation of a program, indicating to what degree objectives and changes take place and supporting the elaboration or redimensioning of the policies and programs.

The political function consists in providing information that help social subjects in their social struggles for the social control of public policies.

The academic function reveals determinations and contradictions contained in the process and in the control of the public policies, revealing the deeper meanings of this policy (its essence) for the construction of knowledge (SILVA, 2013, p. 44, emphasis by the author). 
Possible impacts of the income transfer programs in Latin America: highlighting important fragments of a comparative study about the Family Grant program in Brazil, the New Regime for Family Allowances in Uruguay and the Universal Allowance per Child in Argentina

The objective of this item is to discuss, from a comparative perspective, possible impacts of the three conditional income transfer programs that constitute the object of a study conducted about the: Family Grant program in Brazil; the New Regime for Family Allowances - the Equity Plan (AFAM-PE) in Uruguay and the Universal Allowance per Child for Social Protection (AUH), in Argentina.

This study is based on a broad review of the literature that addresses the results of evaluative studies already conducted about the programs in focus, encompassing studies conducted by government and nongovernment institutions, as well as academic research.

Considering the difficulties involved in a comparative study of programs implemented in three countries, we sought to consider the specificities of each one of the countries and the specificities of the programs themselves, to then establish a comparison between the three programs, considering possible impacts they may have on the following indicators: poverty and inequality; education, health, nutrition and food safety; and adult and child labor, which are analyzed below.

\section{Possible impacts on indicators of poverty and inequality}

In Brazil, Silva, Arregui and Yazbek (2016) identify a set of studies that demonstrate a significant and continuous decline of poverty and inequality since 2001 (BARROS et al., 2007a; 2007b; BRASIL, 2012; FURTADO, 2013; INSTITUTO BRASILEIRO DE GEOGRAFIA E ESTATÍSTICA, 2008; UNIVERSIDADE ESTADUAL DE CAMPINAS, 2014; SOARES et al., 2007; SOUZA; OSÓRIO, 2013).

In the same direction, the National Household Sample Study (PNAD) 2014, conducted in Brazil, identified that the rate of extreme poverty fell to $2.8 \%$, representing nearly one third of the percentage registered in 2004 (7.6\%), the year that the Family Grant began to be implemented in Brazil. According to the same source, the poverty rate maintained its tendency to decline in the country, reaching $7.3 \%$ of the population, in 2014, which represented a drop of nearly $70 \%$ in relation to 2004 (INSTITUTO BRASILEIRO DE GEOGRAFIA E ESTATÍSTICA, 2015). About the distribution of income in Brazil, measured by the Gini Index, the National Household Sample Study of 2014 found that, considering the household incomes, this indicator declined from 0,535 in 2004 , to 0,494 in 2014 , while the $10 \%$ poorest portion of the population had an increase of income of $6.2 \%$, representing nearly three times the variation in income of the $10 \%$ most wealthy, which was $2.1 \%$.

Studies conducted by Silva, Arregui and Yazbeck (2016) allowed concluding that the income transfer programs implemented in Brazil, combined with economic growth, monetary stability, decreased unemployment, increased insertion of workers in social security, the rise of worker income and mainly the adjustment of the minimum wage above the inflation rate, have contributed to the reduction of rates of inequality and poverty, and mainly to the reduction of extreme poverty ${ }^{5}$ (BARROS et al., 2006; SOARES, S. V. et al., 2006; SOARES, S. S. D., 2006; SOARES et al., 2007; SOARES; RIBAS; OSÓRIO, 2007; INSTITUTO DE PESQUISA ECONÔMICA APLICADA, 2008, 2009, 2010, 2011; SOUZA, 2013). In fact, conclusion of the study by Souza and Osório (2013) highlights that the extremely poor portion of the population has little condition to benefit from the expansion of the labor market and increases in the minimum wage, making the Family Grant program highly significant for this population segment.

Seeking to understand the contribution of the New Regime for Family Allowances in the reduction of poverty and inequality in Uruguay, studies conducted by Carballo and Vecinday (2014) consider that the important expansion of the program's coverage have not been expressed in a significant impact on the incidence of indigence and even less on poverty, given the low magnitude of the monetary transfers. Nevertheless, a reduction in the gap and severity of indigence was highlighted, and a decrease in the average distance of households in relation to the poverty line (MIDAGLIA; SILVEIRA, 2011).

In relation to the Universal Allowance per Child program in Argentina, according to Soto and Escurra (2014), various evaluative studies were conducted in the first year of the program's implementation and presented positive projections about indicators of poverty, indigence, inequality and relative vulnerability, especially in the most needy regions of the country. One highlight was attributed to the historically most vulnerable population groups (such as children, single mothers or large families) which had lower probability of indigence than the rest of the population, although there was a lower reduction in poverty indicators, considering that the assistance programs should be complemented with massive employment policies (AGIS; CAÑETE; PANIGO, 2010; BERTRANON, 2010; GASPARINI; CRUCES, 2010). 
In comparative terms, there was consensus among the various studies about the possible impact on indicators of poverty and social inequality: the three programs under focus have contributed to a significant reduction of extreme situations of indigence of their beneficiary populations, with lower repercussion on poverty and with few indications that they reduce social inequality. This allows concluding that these programs alleviate extreme situations, but on their own are incapable of breaking with the intergenerational poverty that is their strategic objective (SILVA; LIMA, 2016).

\section{Possible impacts on indicators of education, health, nutrition and food and nutritional security}

In terms of the possible impacts in the field of education, a comparison between the programs in Brazil, Uruguay and Argentina indicates that they have similar results. In fact, the studies consulted do not provide conclusive information about the final objectives of the programs for human development such as improvements in education. The educational effects are concentrated in increased school registration and the maintenance of higher attendance and lower dropout rates, aspects that are directly related to the conditionalities imposed in the realm of education.

An important aspect identified in relation to the programs in Uruguay and Argentina is their greater contribution to high school education and the indication that the improved living conditions of the families provided by the transfer of income and the adoption of the conditionality of school attendance can be contributing to a revalorization of education.

About possible impacts of the conditional income transfer programs on health, conclusive results of the conditional income transfer programs were not identified, unless it is considered that improved food consumption, made possible by the monetary transfers, can be contributing to the decrease in infant mortality and the malnutrition of children. The possible impact on food and nutritional security may be due to the monetary benefits provided in the three programs being analyzed.

When comparing the possible impacts on food and nutritional security of the beneficiary populations of the three income transfer programs, a consensus was registered about the possible contributions to the rise in rates of food and nutritional security, due to the regularity of the monetary transfers and their greater use for food, which does not mean, however, that food insecurity was overcome among the beneficiaries of the programs (SILVA; LIMA, 2016).

\section{Possible impacts on adult and child labor}

In comparative terms, the studies consulted register a convergence about the possible impacts of the three conditional income transfer programs on these indicators, highlighting as the main conclusion that the beneficiaries of the programs are to a large degree inserted in the labor market, but that this insertion is intensely marked by precarious, unstable labor with low salaries and without signed working papers. This, however, does not mean that informal and precarious labor is the first choice or preference of the beneficiary public, but that it may be the only possibility they have to participate in labor markets.

In terms of child labor, no indications were found about direct contributions of the programs to the reduction of its incidence. In the case of Brazil, studies like the National Home Sampling Study, conducted each year by the Brazilian Institute of Geography and Statistics (IBGE), have found significant reductions in the rates of child labor in recent years, although data are not available to gauge the specific contribution of the Family Grant program to this aspect, and it is only possible to consider that the greater time dedicated to school can decrease the vulnerability of children to child labor (SILVA; LIMA, 2016).

\section{Final considerations}

In conclusion, it is important to reinforce the complexity and limits to identifying possible impacts of social programs. This is because a social program is situated in an open socio-economic and political reality, which receives direct and indirect influences from situations in progress in the social reality. Equally, it influences the same reality in which it is located. For this reason it is more adequate to speak of possible impacts (SILVA; LIMA, 2016).

In the case of the income transfer programs implemented in Brazil, Argentina and Uruguay, the empiric object of this article, this complexity became even greater because the programs propose combining what we call monetary benefits with a broad group of non-monetary complementary or beneficial actions. The three 
programs also have quite different scopes and were implemented at different times ${ }^{6}$. Moreover, although the socio-historic and economic realities of the Latin American countries are similar, there are differences and specificities that mark the standard of social protection in each country. These programs are implemented in different realities, in terms of the size of the countries, their level of development, the level of social protections, the public reached by the programs, their levels of implementation. They are also implemented in contexts where other programs are conducted.

The countless evaluative studies reviewed for this research about the impacts of the three programs in Latin America allow inferring the prevalence of the possible impacts, which are mostly located in the immediate living conditions of the beneficiary public of the programs. Isolated changes were identified, which in some way may have contributed to decreasing the monetary poverty of the beneficiary families while they are inserted in the programs. This is highlighted by the decreasing rates of extreme poverty, but there has been an insignificant decrease in social inequality. In the areas in which the studies did find an impact, such as education, the changes are mainly in relation to an increase in school attendance and a decrease in school dropouts, with no significant changes in the school performance of the students who are beneficiaries of the programs.

In healthcare, the changes are mainly restricted to the participation of children from the beneficiary families in vaccination and weight control campaigns, and pregnant women received pre-natal care. Among the possible impacts, there was a significant reduction in infant mortality, presumably due to the improved nutrition, made possible by the regular monetary support and by the way that it was used, particularly for purchasing foods, contributing to reduced rates of food insecurity, although this is still high. It is important to consider, however, that the data do not present evidence that integral healthcare has been guaranteed to the beneficiaries of the income transfer programs.

In terms of insertion in the labor market, the data from the studies reviewed reveal that the large majority of the beneficiaries, when they are not unemployed, are mostly engaged in informal work, and have limited participation in the formal labor market. This means they are mostly involved in precarious, unstable work at low wages.

For this reason, it can be inferred that the possible impacts resulting from these Latin American conditional income transfer programs on the beneficiary families are concentrated on immediate changes in living conditions. The programs are not capable of having a significant impact on the formation of human capital, which is indicated as a strategic objective of these programs and a necessary condition for overcoming intergenerational poverty. The conclusion is thus that the possible impacts of these programs are concentrated on an immediate relief of poverty, with greater incidence on changes in extreme poverty and on immediate living conditions ${ }^{7}$.

\section{References}

AGIS, E.; CAÑETE, C.; PANIGO, D. El Impacto de la Asignación Universal por Hijo en Argentina. CEIL-PIETTE CONICET, 2010. Disponível em: <http://www.ceil-piette.gov.ar/docpub/documentos/AUH_en_Argentina.pdf > Acesso em: 23 abr. 2015.

BARROS, R. P. de et al. A importância da queda recente da desigualdade na redução da pobreza. Texto para Discussão, Rio de Janeiro, n. 1256, p. 7-22, jan. 2007a. Disponível em: $<$ http://www.ipea.gov.br/portal/index.php?option=com_content\&view=article\&id=4819>. Acesso em: 10 jun. 2013.

. et al. A queda recente da desigualdade de renda no Brasil. Texto para Discussão, Rio de Janeiro, n. 1258, p. 7-22, jan. 2007b. Disponível em: <http://www.ipea.gov.br/portal/index.php?option=com_content\&view=article\&id=4822>. Acesso em: 10 jun. 2013. . et al. Uma análise das principais causas da queda recente na desigualdade de renda brasileira. Texto para Discussão, Rio de

Janeiro, n. 1203, p. 7-28, ago. 2006. Disponível em: <http://www.ipea.gov.br/portal/ index.php?option=com_content\&view=article\&id=4366>. Acesso em: 10 jun. 2013.

BENTURA ALONSO, J. P.; VECINDAY GARRIDO, M. L. La evaluación “tautológica” de los Programas de Transferencia de Renta Condicionada. Revista de Políticas Públicas, São Luís, v. 17, n. 1, p. 139-148, jan./jun. 2013. Disponível em: <http:// www.periodicoseletronicos.ufma.br/index.php/rppublica/article/view/1733/560>. Acesso em: 23 abr. 2015.

BERTRANOU, F. (Coord.) Aportes para la construcción de un piso de protección social en Argentina: el caso de las asignaciones familiares. Buenos Aires: OIT, 2010. Disponível em: <http://www.ilo.org/buenosaires/publicaciones/WCMS_BAI_PUB_139/lang--es/ index.htm>. Acesso em: 23 mar. 2012.

BRASIL. Ministério do Planejamento, Orçamento e Gestão (Coord.) Indicadores de Desenvolvimento Brasileiro 2001- 2012. [Brasília, DF], [2014?]. Disponível em: <http://www.planejamento.gov.br/secretarias/upload/Arquivos/publicacao/ indicadores_de_desenvolvimento.pdf $>$. Acesso em: 23 jun. 2013.

CARBALLO, Y.; VECINDAY, L. Mapeamento y análisis de posibles impactos de las AFAM-PE. In: BENTURA, P. et al. Nuevo Régimen de Asignaciones Familiares: caracterización de sus dimensiones configurativas. Montevideo: [s. n.], 2014. Mimeo. p. 86-102. 
FUNDAÇÃO DE DESENVOLVIMENTO DA PESQUISA; UNIVERSIDADE FEDERAL DE MINAS GERAIS. Estudo sobre o Perfil das Famílias que sofreram repercussões sobre o benefício do Programa Bolsa Família em decorrência do processo de revisão cadastral. Caderno de Estudos Desenvolvimento Social em Debate, Brasília, DF, n. 16, p. 59-62, 2014. Disponível em: <https:// aplicacoes.mds.gov.br/sagirmps/ferramentas/docs/Caderno\%20de\%20Estudo\%20N.16.pdf $>$. Acesso em: 15 jun. 2016.

FURTADO, B. A. Índice de Vulnerabilidade das Famílias (2000-2010): Resultados. Texto para Discussão, Brasília, DF, n. 1835 , p. 7 36, maio 2013. Disponível em: <http://repositorio.ipea.gov.br/bitstream/11058/1214/1/TD_1835.pdf >. Acesso em: 10 jun. 2013. GASPARINI, L.; CRUCES, G. Las Asignaciones Universales por Hijo: Impacto, Discusión y Alternativas. Documentos de Trabajo (CEDLAS), La Plata, n. 102, jul. 2010.

INSTITUTO BRASILEIRO DE GEOGRAFIA E ESTATÍSTICA. Pesquisa Nacional por Amostra de Domicílios: síntese de indicadores 2007. Rio de Janeiro, 2008.

. Pesquisa Nacional de Amostra por Domicílios: síntese de indicadores 2014. Rio de Janeiro, 2015.

INSTITUTO DE PESQUISA ECONÔMICA APLICADA. Desigualdade e pobreza no Brasil metropolitano durante a crise internacional: primeiros resultados. Comunicado da Presidência, Brasília, DF, n. 25, p. 2-8, 04 ago. 2009. Disponível em: $<\mathrm{http}$ //repositorio.ipea.gov.br/bitstream/11058/5306/1/Comunicado_n25_Desigualdade.pdf $>$. Acesso em: 10 jul. 2010.

. Mudanças recentes na pobreza brasileira. Comunicados do IPEA, Brasília, DF, n. 111, p. 3-14, 15 set. 2011. Disponível em:

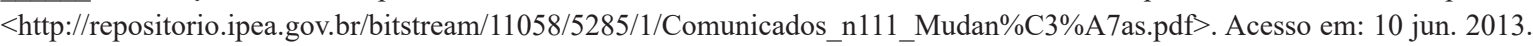
. Pobreza e riqueza no brasil metropolitano. Comunicado da Presidência, Brasília, DF, n. 7, p. 2-15, ago. 2008. Disponível em:

$<$ http://repositorio.ipea.gov.br/bitstream/11058/5531/1/Comunicado_n7_Riqueza.pdf $>$. Acesso em: 10 jun. 2013.

. Previdência e Assistência Social: efeitos no rendimento familiar e sua dimensão nos Estados. Comunicados do IPEA, Brasília,

DF, n. 58, p. 3-18, 22 jul. 2010. Disponível em: <http://repositorio.ipea.gov.br/bitstream/11058/5294/1/ Comunicados_n59_Previd\%C3\%AAncia.pdf $>$. Acesso em: 10 jul. 2010.

MIDAGLIA, C.; SILVEIRA, M. Políticas sociales para enfrentar los desafíos de la cohesión social: los nuevos Programas de Transferencias Condicionadas de Renta en Uruguay. In: SOLANO, C. B.; COHEN, N. (Coord.). Perspectivas críticas sobre la cohesión social: desigualdad y tentativas fallidas de integración social en América Latina. Buenos Aires: CLACSO, 2011. p. 225-249.

NEMES, M. I. B. Avaliação em saúde: questões para os programas de DST/AIDS no Brasil. Rio de Janeiro: Associação de Brasileira Interdisciplinar de AIDS, 2001. (Coleção ABIA: Fundamentos de Avaliação, n. 1).

NEVES, M. E. R. Proteção Social?! Bolsa Família e Trajetórias Sociais de Egressos. 2010. Tese (Doutorado em Sociologia)-Programa de Pós-Graduação em Sociologia, Universidade Federal da Paraíba, João Pessoa, 2010.

ROCHE, C. Avaliação de impactos do trabalho de ONGs: aprendendo a valorizar as mudanças. 2. ed. São Paulo: Cortez, 2000. SILVA, M. O da S. e; ARREGUI C.; YAZBEK, M. C. Mapeando e analisando possíveis impactos do Bolsa Família. In: (Coord.). O Bolsa Família: verso e reverso. Campinas: Papel Social, 2016. p. 145-192.

. (Coord.). O significado e a realidade de possíveis impactos do Bolsa Família: das mudanças imediatas nas condições de vida das famílias beneficiárias ao alcance dos objetivos estratégicos. In: SIMPÓSIO INTERNACIONAL ESTADO, SOCIEDADE E POLÍTICAS PÚBLICAS, 1., 2016, Teresina. Anais... Teresina: UFPI, 2016.

. (Coord.). Os Programas de Transferência de Renda na América Latina e Caribe. São Paulo: Cortez, 2014.

. et al. Avaliação de políticas e programas sociais: uma reflexão sobre o conteúdo teórico e metodológico da pesquisa avaliativa. In: . Pesquisa Avaliativa: aspectos teórico-metodológicos. 2. ed. São Paulo: Veras, 2013. p. 17-108.

. et al. Os egressos do Bolsa Família no Maranhão: quem são, como vivem e o significado do Programa para suas vidas. Caderno de Estudos Desenvolvimento Social em Debate, Brasília, DF, n. 27, p. 246-251, 2016. Disponível em: <https://aplicacoes.mds.gov.br/ sagirmps/ferramentas/docs/Caderno\%20de\%20Estudos\%2027.pdf>. Acesso em: 15 jun. 2016.

.; LIMA, V. F. S. de A. Avaliação e impactos dos Programas de Transferência de Renda: alcances, percursos e dimensões ainda pouco exploradas. In: ____. (Coord.). O mito e a realidade no enfrentamento à pobreza na América Latina: estudo comparado de programas de transferência de renda no Brasil, Argentina e Uruguai. São Paulo: Cortez, 2016. p. 279-326.

. Avaliando o Bolsa Família: unificação, focalização e impactos. 2. ed. São Paulo: Cortez, 2014.

.; YAZBEK, M. C.; COUTO, B. R. Pobreza como categoria teórica e análise das matrizes que fundamentam o desenho e a implementação dos PTRC. In: ___ (Coord.). O mito e a realidade no enfrentamento à pobreza na América Latina: estudo comparado de programas de transferência de renda no Brasil, Argentina e Uruguai. São Paulo: Cortez, 2016. p. 91-118.

SOARES, F. V. et al. Programas de Transferência de Renda no Brasil: impactos sobre a desigualdade e a Pobreza. Texto para Discussão, Brasília, DF, n. 1228, p. 7-40, out. 2006. Disponível em: <http://www.ipea.gov.br/portal/index.php?option=com content\&view=article\&id=4374>. Acesso em: 10 maio 2013.

.; RIBAS, R. P.; OSÓRIO, R. G. Avaliando o Impacto do Programa Bolsa Família: uma comparação com programas de transferência condicionada de renda de outros países. IPC Evaluation Note, Brasília, DF, n. 1, p. 1-13, dez. 2007.

SOARES, S. S. D. Distribuição de Renda no Brasil de 1976 a 2004 com ênfase no período 2001 e 2004. Texto para Discussão, Brasília, DF, n. 1166, p. 7-27, fev. 2006. Disponível em: <http://www.ipea.gov.br/portal/index.php?option=com content\&view $=$ article\&id=4335>. Acesso em: 10 jun. 2013.

. et al. Programas de Transferência de Condicionada de Renda no Brasil, Chile e México: impactos sobre a desigualdade. Texto para Discussão, Brasília, DF, n. 1293, p. 7-27, jul. 2007. Disponível em: <http://www.ipea.gov.br/portal/ 
index.php?option $=$ com_content\&view $=$ article $\&$ id $=4852>$. Acesso em: 10 maio 2013.

SOTO, S. F.; ESCURRA, M. Impactos en la Población Beneficiaria de la AUH y en la Sociedad. In: problematización de las dimensiones constitutivas de la AUH. Buenos Aires: [s. n.], 2014. p. 99-108. Mimeo.

SOUZA, P. H. G. F. de. As Causas Imediatas do Crescimento da Renda, da Redução da Desigualdade e da Queda da Extrema Pobreza na Bahia, no Nordeste e no Brasil entre 2003 e 2011. Texto para Discussão, Brasília, DF, n. 1816, p. 7-23, mar. 2013. Disponível em: $<$ http://www.ipea.gov.br/portal/index.php?option=com_content\&view=article\&id=17228>. Acesso em: 10 jun. 2013.

.; OSÓRIO, R. G. O Perfil da pobreza no Brasil e as mudanças entre 2003 e 2011. In: CAMPELLO, T.; NERI, M. C. (Org.). Programa Bolsa Família: uma década de inclusão e cidadania. Brasília, DF: Ipea, 2013. cap. 8, p. 139-155.

UNIVERSIDADE ESTADUAL DE CAMPINAS. Desigualdade e pobreza nas famílias metropolitanas: diagnóstico e recomendações para a redução das desigualdades. Caderno de Estudos Desenvolvimento Social em Debate, Brasília, DF, n. 16, p. 315-317, 2014. Disponível em: $<$ https://aplicacoes.mds.gov.br/sagirmps/ferramentas/docs/Caderno\%20de\%20Estudo\%20N.16.pdf $>$. Acesso em: 16 jun. 2016.

\section{Notas}

1 This article includes partial results of studies conducted with support from the Coordination for the Improvement of Higher Education Personnel (CAPES) and the National Council for Scientific and Economic Development (CNPq), Brazilian government agencies that support research and education of human resources.

2 The results of the exploratory study mentioned are found in the book by Silva (2014) and the results of the comparative study are found in the book by Silva (2016).

3 In a bibliographic survey conducted by Silva et al. (2016) about studies of people leaving the Family Grant program in Maranhão, only two studies were identified in the specific field of this subject: FUNDAÇÃO DE DESENVOLVIMENTO DA PESQUISA; UNIVERSIDADE FEDERAL DE MINAS GERAIS. Estudo sobre o Perfil das Famílias que sofreram repercussões sobre o benefício do Programa Bolsa Família em decorrência do processo de revisão cadastral. Caderno de Estudos Desenvolvimento Social em Debate, Brasília, DF, n. 16, p. 59-62, 2014.; NEVES, M. E. R. Proteção Social?! Bolsa Família e Trajetórias Sociais de Egressos. 2010. Tese (Doutorado em Sociologia)-Programa de PósGraduação em Sociologia, Universidade Federal da Paraíba, João Pessoa, 2010.

4 About the theoretical category of poverty and concepts about poverty that support the proposals and practices of these Latin American income transfer programs see: SILVA, M. O. da S. e; YAZBEK, M. C.; COUTO, B. R. Pobreza como categoria teórica e análise das matrizes que fundamentam o desenho e a implementação dos PTRC. In: . (Coord.). O mito e a realidade no enfrentamento à pobreza na América Latina: estudo comparado de programas de transferência de renda no Brasil, Argentina e Uruguai. São Paulo: São Paulo: Cortez, 2016. p. 91-118.

5 It is highlighted that this reality has changed in Brazil since 2014, when Brazil's gross national product grew only $0.02 \%$, a situation that was aggravated in 2015 and 2016 by high inflation, which had a negative repercussion on employment and worker income, initiating a strong process of economic adjustment that has been restricting the social actions conducted by the federal government.

6 Brazil's Family Grant program was began to be implemented in October 2003; the Family Allowance Program (AFAM-PE) in Uruguay was enacted in January 2008 and the Universal Allowance per Child Program (AUH) in Argentina began in November 2009.

7 As can be expected, similar conclusions were identified in a specific study about the evaluatin of impacts of Brazil's Family Grant program. See: Silva, Arregui and Yazbek (2016).

\section{Maria Ozanira da Silva e Silva}

maria.ozanira@gmail.com

Doctor in Social Work from the Pontifical Catholic University of São Paulo (PUC-SP)

Professor at the Graduate Program in Public Policies of the Federal University of Maranhão (UFMA)

\section{Valéria Ferreira Santos de Almada Lima}

valmadalima@gmail.com

Doctor in Public Policies from the Graduate Program in Public Policies of the Federal University of Maranhão (UFMA)

Professor at the Economics Departament and at the Graduate Program in Public Policies of the Federal University of Maranhão (UFMA)

\section{UFMA}

Avenida dos Portugueses, 1966

São Luís - Maranhão - Brazil

CEP: $65.080-805$ 


\section{Funding}

Coordination for the Improvement of Higher Education Personnel (CAPES) and National Council for Scientific and Technological Development (CNPq). Project title: Conditional Income Transfer Programs in Latin America: a comparative study - Family Grant (Brazil), New Regime for Family Allowances - AFAM-PE (Uruguay) and Universal Allowance per Child (Argentina). This project was approved and funded by the Coordination for the Improvement of Higher Education Personnel - CAPES (Edict CGCI No. 072/2010) and by the National Council for Scientific and Technological Development - CNPq (Universal Edict CNPq No. 14/2011) and was coordinated by Professor Maria Ozanira da Silva e Silva from the Graduate Program in Public Policies. Project implementation period: from 2013 to 2016.
Authors' contributions

Both authors were equally responsible for the study conception and design.

Ethics approval and consent to participate Not applicable.

\section{Consent for publication}

Not applicable.

\section{Competing interests}

There are no competing interests. 